\title{
PROPRIETARY POLICY AND PRODUCTION
}

\author{
Byeongju Jeong
}
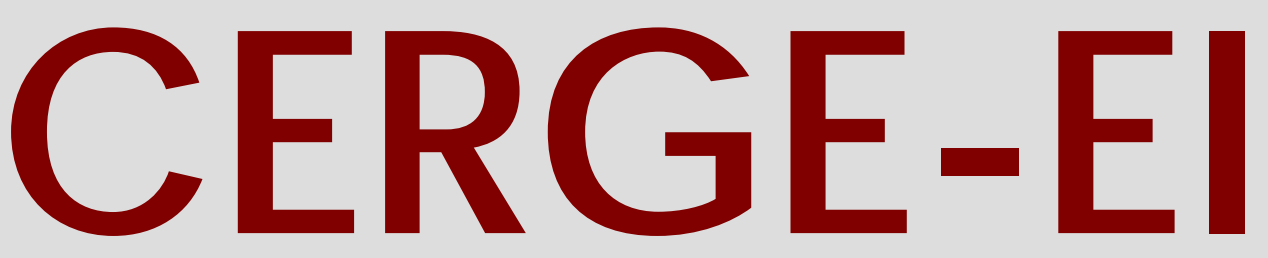

Charles University Centerfor Economic Research and Graduate Education Academy of Sciences of the Czech Republic Ec onomic s Institute 


\title{
Working Paper Series $\quad 287$ (ISSN 1211-3298)
}

\section{Proprietary Policy and Production}

\author{
Byeongju Jeong
}

\author{
CERGE-EI \\ Prague, January 2006
}


ISBN 80-7343-082-7 (Univerzita Karlova v Praze, CERGE)

ISBN 80-7344-071-7 (Národohospodářský ústav AV ČR, Praha) 


\title{
Proprietary Policy and Production
}

\section{Byeongju Jeong}

\section{CERGE-EI *}

January 2006

\begin{abstract}
I present a model of a proprietary regime with opportunities for direct production (e.g., plantation cultivation, mining extraction). The premise is that direct production is a superior method of appropriation than taxation. The tax and spending policy of the regime distorts the resource allocation in favor of direct production and at a loss of private production; the welfare of the population suffers while the regime benefits. I examine the relevance of the model to the policies of actual proprietary regimes.
\end{abstract}

\begin{abstract}
Abstrakt
Ve své studii uvádím model diktátorského režimu s možností vlastní přímé produkce.(např. kultivace plantáží, dobývání nerostů) Premisou je, že př́ímá produkce je lepší metodou přivlastnění než politika zdanění. Daňové a výdajové politiky režimu narušují přirozenou alokaci zdrojů ve prospěch př́mé produkce a naopak škodí produkci soukromé. Z toho vyplývá, že zatímco obyvatelstvo strádá, režim z toho těží. Ve své práci zkoumám relevanci modelu v rámci soudobých diktátorských režimů.
\end{abstract}

\section{Email: byeongju.jeong@cerge-ei.cz}

* A joint workplace of the Center for Economic Research and Graduate Education, Charles University, and the Economics Institute of the Academy of Sciences of the Czech Republic.

Address: CERGE-EI, P.O. Box 882, Politických vězňů 7, Prague 1, 111 21, Czech Republic. 


\section{Introduction}

In this paper, I study the policy of a proprietary regime when it has opportunities for its own production. Good examples are the Trujillo regime in the Dominican Republic that operated sugar plantations, and the Mobutu regime in Zaire that had access to mineral resources. Both regimes practiced policies that favored their own production over private production, and the welfare of the population at large suffered as a result. I present a model that formalizes a rationale for allocating resources to such an effect, focusing on taxing and spending as the policy instruments. Then I examine the policies of actual proprietary regimes in light of the model.

The starting point is to distinguish two types of appropriation: one is to appropriate the output leaving the production to private producers, the other to appropriate the production process itself. The former has the standard trade-off of the tax rate and the tax base. Absent the trade-off, the latter is a superior means of extracting surplus from production. However, it is not applicable to all production: mining and plantation agriculture are conducive to standardized methods and production by hired workers whereas commerce and peasant agriculture are not. ${ }^{1}$ If a proprietary regime directly produces in some sectors, tax and spending policies not only generate tax revenue but also shift resources across the private and the regime-controlled sectors. Significantly, a lost tax base such as discharged labor in the private sectors can be recaptured in the regime-controlled sectors. In other words, lost tax revenue can be recovered as production surplus. Consequently, the tax and spending policies are more oppressive on private production than without the regime-controlled sectors, and the population suffers from diminished after-tax surplus.

Section 2 presents a model economy that formalizes the above intuition. As mentioned, the model most readily applies to proprietary regimes that have significant opportunities

\footnotetext{
${ }^{1}$ Underlying the difference are agency issues such as the degree to which production can be monitored: the more easily production can be monitored, the greater share of surplus can be extracted without violating the incentive constraints of the agents.
} 
for their own production. Section 3 discusses as examples the regimes of Trujillo and Mobutu, and the regimes of the Mughal and the Ottoman empires in the more distant past. These regimes exhibit the features of the model, illustrating its relevance. Certainly, the model does not provide a comprehensive account of the policies of these regimes. For one thing, no regime is entirely proprietary: one can find an element of benevolence in each example. Perhaps more significantly, the model abstracts from dynamic issues, in particular the (expected) tenure of the regime. Even a proprietary regime would moderate its policy if it expects to gain from the expanded tax base in the long run, but not if it expects a short period of rule (McGuire and Olson 1996). ${ }^{2}$ Conversely, a regime may be able to prolong its tenure by implementing a moderate policy (Grossman and Noh 1994). ${ }^{3}$ The model, being a static one, would seem relevant to long-lasting regimes, and so they are the chosen examples. Still, the concern for survival may have been an important factor in their policy making.

\section{The Model Economy}

Consider the following economy. There is an autocrat and a subject. The autocrat personifies a proprietary regime. Having a single subject is a short cut to modeling multiple heterogeneous subjects. ${ }^{4}$ There are two sectors, denoted by $i=1,2$. The production functions are:

$$
Y_{i}=A_{i} L_{i}^{\alpha_{i}} Z_{i}^{\gamma_{i}}
$$

where $A_{i}$ is the productivity parameter, $L_{i}$ is the labor input, and $Z_{i}$ is the government input or spending. Assume that $\alpha_{i}+\gamma_{i}<1$ for $i=1,2$. For economic intuition, imagine

\footnotetext{
${ }^{2}$ Buchanan and Lee (1982) makes this point in the context of policy-making by an elected government.

3 Or, for that matter, by implementing policies that would reduce the capacity for rebellion (Robinson 1997).

4 That is, the results are robust to assuming a continuum of ordered subjects whose private-sector labor productivities are equal to the marginal productivities of the private-sector production function in $(1)$.
} 
that there is a fixed input such as land, which lowers the marginal product of the other inputs as output increases. Technically, this assumption insures that the sectoral allocation of resources is continuous in model parameters. The autocrat taxes the output of Sector 1 while he directly produces the output of Sector 2 using hired workers. The operational significance in the distinction is that direct production entitles the autocrat to the entire surplus from production whereas taxation allows him to take away only a portion of the surplus due to the deadweight loss. As discussed, imagine that production in Sector 1 is hardly manageable for the autocrat while production in Sector 2 is readily manageable. ${ }^{5}$ To be descriptive, I'll call Sector 1 the private sector, and Sector 2 the autocrat's sector. The autocrat's utility is:

$$
U_{a}=\tau Y_{1}-Z_{1}+Y_{2}-w L_{2}-Z_{2}
$$

where $\tau$ denotes the tax rate and $w$ the wage rate. The subject is endowed with 1 unit of labor. His utility is:

$$
U_{s}=Y_{1}(1-\tau)+w L_{2}+B\left(1-L_{1}-L_{2}\right),
$$

where $B$ denotes the value of leisure or the productivity of (untaxable) home production. Assume that $A_{1}>\bar{A} \equiv B^{1-\gamma_{1}} /\left(\alpha^{2\left(1-\gamma_{1}\right)} \gamma_{1}^{\gamma_{1}}\right)$. This insures that in equilibrium the marginal return to labor is at least as high as the reservation level $B$, so all labor is allocated in the two sectors. ${ }^{6}$ The subject chooses $L_{1}$ and $L_{2}$ to maximize $U_{s}$, taking as given $\tau, w, Z_{1}$, and $Z_{2}$. The autocrat chooses $\tau, w, Z_{1}$, and $Z_{2}$ to maximize $U_{a}$, knowing their effects on

\footnotetext{
5 A further implicit assumption is that all output is taxable. See an elaboration on relaxing this assumption in footnote 14 .

6 If some labor is idle, the connection between the private and the autocrat's sectors is lost in the model. An extension would model the three-way labor flows among the private sector, the autocrat's sector, and the idle state, through which the policy on the private sector affects the surplus in the autocrat's production. See footnote 12 for an elaboration regarding the informal sector, which can be viewed as the idle state to some extent.
} 
$L_{1}$ and $L_{2} \cdot{ }^{7}$ The equilibrium is $\tau, w, Z_{1}$, and $Z_{2}$ that solve the autocrat's problem, and $L_{1}$ and $L_{2}$ that solve the subject's problem, given $\tau, w, Z_{1}$, and $Z_{2}$.

\subsection{The Policy Bias}

The policy bias for the autocrat's production and against the private production can be seen in terms of the sectoral allocation of resources in equilibrium. Observe in (3) that the subject will choose $L_{1}$ so that the marginal return is equal to the opportunity cost:

$$
\frac{\partial Y_{1}}{\partial L_{1}}=\frac{B}{1-\tau}
$$

It is implicit in (4) that in equilibrium $w \leq B$ and $\tau$ is large enough so that $L_{1} \leq 1$. Otherwise, the autocrat can gain by reducing $w$ and/or raising $\tau$. If $w<B$, on the other hand, the autocrat will not be able to attract any labor to his production, i.e., $L_{2}=0$. Given the parameter restriction on $A_{1}$ and conditional on $L_{2}=0$, I can show that the autocrat's tax and spending policy is set so as to have all labor allocated in the private sector, i.e., $L_{1}=1$. In other words, the tax and spending policy is operating on the downward slope of the Laffer curve at all levels of $L_{1}$. The autocrat can improve on this situation by raising the tax rate, lowering private-sector spending, and offering wage at the reservation level $B$, thereby shifting labor from private to his own production, until the marginal loss of tax revenue net of spending (i.e., $\tau Y_{1}-Z_{1}$ ) is exactly compensated by the marginal gain in production surplus (i.e., $Y_{2}-w L_{2}-Z_{2}$ ). Therefore, in equilibrium

$$
w=B
$$

and

$$
L_{1}+L_{2}=1
$$

\footnotetext{
7 Note that the autocrat chooses a policy once and for all before the subject chooses the labor supply. Thus the model abstracts from the issue of time consistency. As mentioned, the model can be interpreted as that of a long-run policy made by a long-lasting regime.

I could add the rationing of employment in Sector 2 as an option for the autocrat, but the autocrat has no incentive to ration given the parameter restriction on $A_{1}$. See Section 2.1 for an intuitive explanation.
} 
Now from (2), I can derive:

$$
\frac{\partial Y_{2}}{\partial L_{2}}=\frac{\partial Y_{1}}{\partial L_{1}}-\frac{B\left(1-\alpha_{1}\right)}{\alpha_{1}}
$$

which leads to the following proposition.

Proposition 1. The marginal labor productivity is higher in the private sector than in the autocrat's sector.

For an intuitive understanding, imagine that the marginal productivity is equal across the two sectors. By raising the tax rate, the autocrat gains additional revenue while the sectoral labor reallocation has no consequences on the autocrat's utility: the lost revenue in the private sector is recaptured as surplus in the autocrat's sector. Thus, the equilibrium tax rate is set above the allocatively efficient rate and, at the margin, labor is allocated to the autocrat's sector despite its lower productivity. In other words, the autocrat's policy promotes his production at the expense of private production. Given (7), I can further derive:

$$
\frac{\partial Y_{1}}{\partial Z_{1}}=\frac{\partial Y_{2}}{\partial Z_{2}}=1
$$

Thus, given the sectoral labor allocation, the government input is efficiently allocated. In comparison to the jointly efficient allocation, however, the government input is excessively provided in the autocrat's sector while it is inadequately provided in the private sector.

\subsection{The Subject's Welfare}

A further implication of the policy bias can be seen in terms of how the equilibrium changes as the productivity of the autocrat's production $A_{2}$ increases, fixing all other parameters. From (4) and (7), I have:

$$
\begin{aligned}
& L_{1}=\tilde{A}_{1}\left(\frac{1}{1-\tau}\right)^{-\rho_{1}} \text { and } \\
& L_{2}=\tilde{A}_{2}\left(\frac{1}{1-\tau}-\frac{1-\alpha_{1}}{\alpha_{1}}\right)^{-\rho_{2}},
\end{aligned}
$$


where $\tilde{A}_{i} \equiv\left(A_{i} B^{\gamma_{i}-1} \alpha_{i}^{1-\gamma_{i}} \gamma_{i}^{\gamma_{i}}\right)^{\frac{1}{1-\alpha_{i}-\gamma_{i}}}$ and $\rho_{i} \equiv\left(1-\gamma_{i}\right) /\left(1-\alpha_{1}-\gamma_{1}\right)$ for $i=1,2$. From (6) and (9), observe that the tax rate $\tau$ will increase, shifting labor from the private to the autocrat's sector. From (1) and (8), observe that the output and the government spending will decrease in the private sector while they will increase in the autocrat's sector. The autocrat's utility will increase since it will do so even without any changes in the tax rate and the government input. The autocrat's production surplus (i.e., $Y_{2}-w L_{2}-Z_{2}$ ) will increase with the inflow of workers, while the tax revenue net of spending (i.e., $\tau Y_{1}-Z_{1}$ ) will decrease since otherwise the tax hike and the spending cut in the private sector would have raised the autocrat's utility even without an increase in productivity. It follows that the gross tax revenue $\tau Y_{1}$ will decrease too. Thus the role of the private sector as a tax base diminishes while the role of the autocrat's sector as a source of production surplus increases. In order to see the change in the subject's utility, rewrite (3) using (4):

$$
U_{s}=B\left(1+\frac{L_{1}\left(1-\alpha_{1}\right)}{\alpha_{1}}\right)
$$

The subject's utility is increasing in the share of labor allocated to private production. Private production is advantageous to the subject since he retains some of the surplus after taxation. Thus the labor shift will reduce the subject's utility. The following proposition summarizes the results.

Proposition 2. A higher productivity in the autocrat's production raises the tax rate and lowers the government spending in the private sector while raising the government spending in the autocrat's sector. The private-sector output and labor input shrink while the autocrat's output and his labor input expand. The tax revenue declines while the autocrat's production surplus rises. The subject's utility falls while the autocrat's utility rises.

Therefore, greater opportunities for the autocrat's production intensify the promotion of his production at the expense of the private production. The subject suffers while the 
autocrat benefits from it. It is worth noting not only the widening of the welfare disparity between them, but also the absolute decline of the subject's welfare.

\subsection{The Aggregate Welfare}

The implication of the policy bias on aggregate welfare is ambiguous: a higher productivity in the autocrat's production may or may not lead to a greater aggregate utility (i.e., $U_{a}+U_{s}$ or, equivalently, $Y_{1}+Y_{2}-Z_{1}-Z_{2}$ ). On the one hand, the higher productivity directly raises the autocrat's output. On the other hand, the labor shift from the higher marginal-product to the lower marginal-product sector worsens the allocative efficiency. I have:

$$
\begin{aligned}
\frac{d\left(U_{a}+U_{s}\right)}{d A_{2}} & =\frac{\partial Y_{2}}{\partial A_{2}}-\frac{d L_{2}}{d A_{2}}\left(\frac{\partial Y_{1}}{\partial L_{1}}-\frac{\partial Y_{2}}{\partial L_{2}}\right) \\
& =L_{2}^{\alpha_{2}} Z_{2}^{\gamma_{2}}\left(1-\sigma\left(\frac{1}{1-\tau}\left(1+\frac{\rho_{2} L_{2}}{\rho_{1} L_{1}}\right)-\frac{1-\alpha_{1}}{\alpha_{1}}\right)^{-1}\right),
\end{aligned}
$$

where $\sigma \equiv \alpha_{2}\left(1-\alpha_{1}\right) /\left(\alpha_{1}\left(1-\alpha_{2}-\gamma_{2}\right)\right)$. The expression in the big bracket is increasing in

$A_{2}$ and, as $A_{2} \rightarrow 0$, converges to $1-\sigma /\left(\tilde{A}_{1}^{1 / \rho_{1}}-\left(1-\alpha_{1}\right) / \alpha_{1}\right)$, which is negative depending on the parameter values. The following proposition follows from these properties.

Proposition 3. If $\psi \equiv\left(\left(1-\alpha_{1}\right)\left(1-\gamma_{2}\right) /\left(1-\alpha_{2}-\gamma_{2}\right)\right)^{\left(1-\gamma_{1}\right)}>1$ and $A_{1}<\bar{A}_{1} \psi$, there is $\bar{A}_{2}$ such that aggregate utility falls as the productivity in the autocrat's production rises up to $\bar{A}_{2}$, and rises as the productivity rises beyond $\bar{A}_{2}$. Otherwise, aggregate utility rises for the whole range of the productivity.

Similarly, the changes in the aggregate output (i.e., $Y_{1}+Y_{2}$ ) depend on the parameter values. I have:

$$
\begin{aligned}
\frac{d\left(Y_{1}+Y_{2}\right)}{d A_{2}} & =\frac{d\left(U_{a}+U_{s}\right)}{d A_{2}}+\frac{d\left(Z_{1}+Z_{2}\right)}{d A_{2}} \\
& =\frac{L_{2}^{\alpha_{2}} Z_{2}^{\gamma_{2}}}{1-\gamma_{2}}\left(1-\left(\frac{\mu}{1-\tau}+\sigma\right)\left(\frac{1}{1-\tau}\left(1+\frac{\rho_{2} L_{2}}{\rho_{1} L_{1}}\right)-\frac{1-\alpha_{1}}{\alpha_{1}}\right)^{-1}\right),
\end{aligned}
$$


where $\mu \equiv \alpha_{2}\left(\gamma_{1}-\gamma_{2}\right) /\left(\left(1-\gamma_{1}\right)\left(1-\alpha_{2}-\gamma_{2}\right)\right)$. The expression in the big bracket, while non-positive, is increasing in $A_{2}$ and, as $A_{2} \rightarrow 0$, converges to $1-\left(\mu \tilde{A}_{1}^{1 / \rho_{1}}+\sigma\right) /\left(\tilde{A}_{1}^{1 / \rho_{1}}-\right.$ $\left.\left(1-\alpha_{1}\right) / \alpha_{1}\right)$. The following proposition follows from these properties.

Proposition 4. If $1-\alpha_{2}-\gamma_{1} \leq 0$ or if $\xi \equiv\left(\left(1-\alpha_{1}\right)\left(1-\gamma_{1}\right) /\left(1-\alpha_{2}-\gamma_{1}\right)\right)^{\left(1-\gamma_{1}\right)}>1$ and $A_{1}<\bar{A}_{1} \xi$, there is $\tilde{A}_{2}$ such that the aggregate output falls as the productivity in the autocrat's production rises up to $\tilde{A}_{2}$, and rises as the productivity rises beyond $\tilde{A}_{2}$. Otherwise, the aggregate output rises for the whole range of the productivity.

Again, the worsening allocative efficiency may outweigh the direct impact of the productivity improvement, leading to a lower aggregate output. That greater opportunities of production can lead to lower levels of output and welfare highlights the perverse impact of the constraints that the autocrat faces in appropriating output.

\section{Examples}

The model is helpful in understanding the policies of Trujillo's regime in the Dominican Republic (1930-1961). Trujillo enriched himself and others around him by directly engaging in various production, in particular that of sugar, an excellent example of a large scale plantation crop (see, for example, Wiarda 1968). By forcing peasants off their land he was able to seize a large portion of land and increase sugar production. ${ }^{8}$ Many of the evicted peasants had no choice but to work as waged labor for sugar production. Trujillo also owned most of sugar mills. The government investment was concentrated on improving the production of sugar and other products that benefited Trujillo; it did little to improve peasant farming. Consequently, peasant farming remained much less modernized and much less productive than most of the other Latin American countries. Turits (2003) makes the

\footnotetext{
${ }^{8}$ In the model, forceful land grab is not an instrument for labor movement. If it were, it would be redundant: taxation can be used to achieve the same outcome. In this sense, taxation can be interpreted more broadly than as the exaction of the produce.
} 
point that the above sugar-peasant-farming policy occurred in the later years of Trujillo's regime, and generally paints a much brighter picture of the regime in the early years than the previous works. The timing of the policy change is still notable: the rise in sugar price coincided with both the expansion of sugar production and the general neglect of peasant farming.

A similar episode of agrarian appropriation can be found in the 17th century Mughal Empire. Habib (1969) notes two types of appropriation, "a demand from outside imposed on the producer" and "a gain accruing as a result of the appropriator's undertaking or organizing the productive process himself" (Page 36). They correspond closely to taxation and the autocrat's own production in the model of this paper. The first type of appropriation steadily intensified causing a crisis in peasant agriculture. The peasant's flight from the land was a common phenomenon and there may have been a net decline in cultivation during the century. At the same time, the land subject to the second type of appropriation expanded. In particular, the ruling class was engaged in the khud-kasht mode of production, a large-scale cultivation of cash crops using hired labor. The labor was supplied by the class of landless labor whose numbers were added by peasants who, unable to pay the tax, abandoned cultivation on their own fields. Thus khud-kasht production encroached upon peasant production through both the conversion of peasant-cultivated lands to khud-kasht lands and the conversion of peasants to laborers, although its expansion was constrained by the limits of supervision and of applicability for non-cash crops. In short, the increasing oppression of peasants helped the ruling class extract the surplus from their khud-kasht production. ${ }^{9}$

\footnotetext{
9 There seem to be multiple possible causes of the changes in appropriation. Habib (1969) and Richards (1995) note the development of the market as a cause of the expansion of commodity production by the ruling class. This fits the logic of increasing oppression in the model. While acknowledging the impact of oppression on commodity production, Habib (1969, 1999) views increasing oppression as a natural consequence of the administrative system, in particular the frequent rotation of local officials.
} 
Mobutu's regime in Zaire (1965-1997) provides another example of proprietary economic policy (see, for example, Young and Turner 1985). ${ }^{10}$ The most enduring source of appropriation for the regime was the mining and processing of copper, diamonds, and other minerals. Notably, when Mobutu came to power, he turned the giant mining firm UMHK into the parastatal Gecamines, whose profits were subsequently diverted to the regime. The regime also appropriated much of the commercial sector in later years, but largely failed to generate profits due to the difficulty of directly managing the production. Government investment was concentrated in mining and the other regime-controlled sectors; almost none went into the agricultural sector. In fact, the policy toward the agricultural sector was oppressive by all accounts. Considering government price-fixing, export duties, arbitrary fines, etc., the effective tax rate on agricultural produce was as high as $50 \%$. As a consequence, there was a massive exodus from the agricultural sector. Although I do not have direct evidence, some of the immigrants would have ended up working in the regime-controlled sectors. ${ }^{11}$

The last and the most speculative example is Ottoman slavery in the 15th and 16th centuries. The empire depended on the massive enslavement of peasant populations drawn from the fringes of its territory (see Coles 1968, for example). ${ }^{12}$ Among other things, the slaves provided much of the soldiery and worked for the households of the ruling class. The nature of the slavery was peculiar: a slave career offered opportunities to become

10 This book provides a good overview of the regime, including economic policy. See Schatzberg (1991) for a political interpretation of the regime. These and other authoritative works were written before the regime's demise. For a journalistic account of the regime, especially of the later years, see Harden (1993) and Wrong (2001).

11 Surely, many ended up in the informal sector, which ballooned under Mobutu's regime. The connection between the rural oppression and the direct-production-based appropriation is weakened to the extent that the informal sector was the immigrants' destination, and that the informal sector is disjointed from the regime-controlled sectors. One can imagine overlaps between the informal and the regime-controlled sectors, and also the role of the former as a pool of easily accessible workers for the latter.

12 It's not clear how massive the enslavement was. The most institutionalized form of enslavement seems to have been the child tributes taken from the Balkans. Sugar (1983) puts the number of 'officially' taken children at 200,000 over a 200 year period, which by itself is not overwhelming. 
commanders, governors, and other positions of power and wealth while peasant life in the outlying regions of the empire was subject to monotony, privations, and misery. Thus the depravation of these regions helped the sultan recruit and retain manpower. ${ }^{13}$ The sultan may have used these regions as a source of manpower rather than as a tax base for the following reason: As one moves away from the center, taxation becomes more difficult due to decreasing security and increasing transportation cost ${ }^{14}$ while it becomes easier to sever a slave's ties to his home village. Consistent with this reasoning, the sultan used taxation as the main form of appropriation in the central regions and further, peasants in the central regions were comparatively lightly burdened.

\section{Conclusion}

The model is built on the premise that direct production is a superior method of appropriation than taxation. The main results follow intuitively. The policy of a proprietary regime, under opportunities for direct production, distorts the resource allocation in favor of direct production and at a loss of private production. The welfare of the population suffers while the regime benefits from direct production. The model, to some extent, seems to fit the proprietary regimes discussed. Surely, the model does not explain the policies of the regimes comprehensively. For instance, the policy of Trujillo's regime may have precipitated its downfall, which suggests the need to explain the policy in conjunction with the tenure of the regime. Also, the labor market channel emphasized in this paper is only

13 This is not to entirely deny the coercive aspect of slavery. In the model, coercion can be incorporated as a means of employing workers while paying a wage below the reservation level. Mechanically, this is equivalent to lowering the value of parameter $B$, with no qualitative impact on the autocrat's policy or policy rationale.

14 The model needs to be adapted to a dynamic setting to capture this line of reasoning, but some intuition can be gained by a comparative-statics analysis. Assume that in the model $\lambda$ fraction of tax revenue is lost during collection. I can show that, holding the other parameters, a rise in the value of $\lambda$ leads to a rise in the tax rate and/or a fall in the private-sector spending, and thereby to a fall in the subject's after-tax surplus in the private sector and a labor flow from the private to the autocrat's sector. In other words, the policy toward the private sector becomes more oppressive. 
one of several through which a proprietary policy could affect the resource allocation and welfare. Another channel may be the product market: a proprietary regime could increase the surplus from its own production by reducing competition from private producers. I leave these issues to future research. 


\section{REFERENCES}

Buchanan, J. and Lee, D. (1982), "Politics, Time, and the Laffer Curve," Journal of Political Economy 90:816-19.

Coles, P. (1968), The Ottoman Impact on Europe, Thames and Hudson, London.

Grossman, H. and Noh, S. (1994), "Proprietary Public Finance and Economic Welfare," Journal of Public Economics 53:187-204.

Habib, I. (1969), "Potentialities of Capitalistic Development in the Economy of Mughal India," Journal of Economic History 29:32-78.

Habib, I. (1999), the Agrarian System of Mughal India, Second, revised edition, Oxford University Press, New Delhi.

Harden, B. (1993), Chapter 1 in Africa: Dispatches from a Fragile Continent, HarperCollins, London.

McGuire, M. and Olson, M. (1996), "The Economics of Autocracy and Majority Rule: The Invisible Hand and the Use of Force," Journal of Economic Literature 34:72-96.

Richards, J. (1995), The Mughal Empire, Cambridge University Press, Cambridge.

Robinson, J. (1997), “A Political Theory of Underdevelopment," Manuscript, Department of Economics, University of Southern California.

Schatzberg, M. (1991), The Dialectics of Oppression in Zaire, Indiana University Press, Bloomington.

Sugar, P. (1983), Southeastern Europe under Ottoman Rule, 1354-1804, University of Washington Press, Seattle.

Turitz, R. (2003), Foundations of Despotism: Peasants, the Trujillo Regime, and Modernity in Dominican History, Stanford University Press, Stanford.

Wiarda, H. (1968), Dictatorship and Development: The Methods of Control in Trujillo's Dominican Republic, University of Florida Press, Gainsville.

Wrong, M. (2001), In the Footsteps of Mr. Kurtz: Living on the Brink of Disaster in the Congo, HarperCollins Publishers, New York.

Young, C. and Turner, T. (1985), The Rise and Decline of the Zairian State, The University of Wisconsin Press, Madison. 
Individual researchers, as well as the on-line and printed versions of the CERGE-EI Working Papers (including their dissemination) were supported from the following institutional grants:

- Economic Aspects of EU and EMU Entry [Ekonomické aspekty vstupu do Evropské unie a Evropské měnové unie], No. AVOZ70850503, (2005-2010);

- Economic Impact of European Integration on the Czech Republic [Ekonomické dopady evropské integrace na ČR], No. MSM0021620846, (2005-2011);

Specific research support and/or other grants the researchers/publications benefited from are acknowledged at the beginning of the Paper.

(c) Byeongju Jeong, 2006

All rights reserved. No part of this publication may be reproduced, stored in a retrieval system or transmitted in any form or by any means, electronic, mechanical or photocopying, recording, or otherwise without the prior permission of the publisher.

Published by

Charles University in Prague, Center for Economic Research and Graduate Education (CERGE) and

Economics Institute (EI), Academy of Sciences of the Czech Republic

CERGE-El, Politických vězñu 7, 11121 Prague 1, tel.: +420 224005 153, Czech Republic.

Printed by CERGE-EI, Prague

Subscription: CERGE-El homepage: http://www.cerge-ei.cz

Editors: Directors of CERGE and EI

Managing editors: Deputy Directors for Research of CERGE and EI

ISSN 1211-3298

ISBN 80-7343-082-7 (Univerzita Karlova v Praze, CERGE)

ISBN 80-7344-071-7 (Národohospodářský ústav AV ČR, Praha) 
CERGE-EI

P.O.BOX 882

Politických vězňů 7

11121 Praha 1

Czech Republic http://www.cerge-ei.cz 